\title{
Internal Costumer Satisfaction: Turkish Air Traffic Control Services
}

\author{
Ertan Çinar*, Ahmet Veral, Soner Demirel \\ Air Traffic Control Department, Anadolu University, Eskişehir, Turkey \\ Email: *ecinar@anadolu.edu.tr
}

How to cite this paper: Cinar, E., Veral, A. and Demirel, S. (2017) Internal Costumer Satisfaction: Turkish Air Traffic Control Services. Theoretical Economics Letters, 7, 406428. https://doi.org/10.4236/tel.2017.73031

Received: January 23, 2017

Accepted: April 3, 2017

Published: April 6, 2017

Copyright $\odot 2017$ by authors and Scientific Research Publishing Inc. This work is licensed under the Creative Commons Attribution International License (CC BY 4.0).

http://creativecommons.org/licenses/by/4.0/

\begin{abstract}
This study traces to determine the internal customers in air traffic control services by using INTQUAL Scale I. In this study, the research method of another study was adapted to the new sector. New questionnaire statements were added. Hence, the dimensions of INTQUAL were changed. Air traffic control system works as a service manufacture system. In this regard, a questionnaire was prepared and applied to the air traffic controllers that work in the 3 international airports in Turkey. Some air traffic controllers that work in same operation feels less satisfied than the others. Also, there is same conclusion in different air traffic control units, too. In previous years, there is no study about air traffic controllers as this study. It is necessary to make the study like that for both providing improvement about the salary regulations and controllers' work conditions.
\end{abstract}

\section{Keywords}

Air Traffic Control Services, Internal Customer Satisfaction, INTQUAL

\section{Introduction}

The difference and variety in the literature causes confusion between the meaning of costumer and consumer. Consumer is "a person, an institution or an organization who has requirement that needs to be satisfied, has money to spend and has claim to spend this money for commercial or personal purpose". Costumer is "in addition to the consumerist feature, with the difference of consumer, the people who are used to buy in specific places" or "a person, an institution or an organization who buys specific brand goods of specific enterprises for commercial or personal purpose". The concept of customer, with difference of consumer, is defined as the view of "loyalty" and it is assumed that the root of this word comes from custom. Because of there is no repurchase behavior of person, institution and organization orderly and frequently, it is not possible to 
define them as a customer [1]. In brief, being a customer has these features; opting to buy specific goods and services orderly, having consumption habit frequently.

According to one of the meaning of customer satisfaction, customer satisfaction is "after buying evaluations of customers which are related to the good or service". According to the other one, customer satisfaction is "favorable result". In second definition, it is stated that "satisfaction" is a feeling about meeting the requirements of the customers after consumption of the good or service by the customer. More generally, customer satisfaction can be defined as "the gladness of customer about the output of consumption".

Customer satisfaction is got involved with "service quality". The reason of this situation is that there is no exact definition for both of them. Essentially, these are different concepts despite similarities of them. There are some reasons about difference of these concepts [1].

The concept of costumer appeared with the start of trade and it has come until today by increasing its significance [2]. Today the establishments spend a lot of money, form their management process as costumer oriented to hold the customers and to obtain new customers. Customer is a consumer who continuously buys goods or gets services from an establishment [3].

Customer is the reason of producing goods or providing services. Customer as a concept includes everybody that is affected by the service or goods produced by the establishment [4]. However, the costumer is not only presented outside the establishment. People or units that work for or are assigned in some duties in the establishment are also costumers.

Workers who work for the establishment or get services, products or goods from each other in the establishment are called as internal costumers. A unit in the establishment is the costumer of the former unit and it can be the supplier of the next unit [5].

In air traffic control services, the situations mentioned above are clearly observed. In an aerodrome where all air traffic control services are given by different units, approach control unit is the costumer of aerodrome control unit for a taking off aircraft; in the meantime, it is the supplier of area control unit. If the internal costumer is satisfied with the units, which are both the costumer and the supplier, this will affect the comfort in the work environment, and it also provides long-term practice for workers. By this way, service quality increases and staff turnover decreases [5].

When the studies which have been done up to this day are analyzed, there aren't any studies related to the controllers who are the customers of each other or about satisfaction levels between units. A study was carried out to determine the satisfaction level between the controllers and their teams and different air traffic control units which their teams work with.

There is not any survey study related to measurement of internal customer satisfaction in air traffic control in Turkey. This survey will also set an example for future studies. As a result of the obtained data, 
1) What affects the satisfaction level of air traffic controllers as internal customers will be determined.

2) To what extent the air traffic controllers are pleased with the units and each other which they interact will be monitored.

3) If there are subjects creating problems, their solutions will be found.

4) Possible problems will be argued.

5) This survey will be used for the future studies on air traffic controllers.

\section{The Description of Costumer and Internal Costumer in Air Traffic Control Services}

Costumers in air traffic control services consist of establishments that get services from air traffic control units. Costumers who get services are establishments that provide commercial air transportation, that maintain their existence with general aviation, that provide trainings and that provide various services related to other aviation activities [6].

According to State Airport Administration data the number of aircrafts that benefitted from air traffic control service in 2015 was 1,815,095. 835,677 of this traffic were domestic routes, 621,764 of it were international routes [7]. 358,654 of this traffic just used Turkish air space and did not land on any airport in Turkey.

Aviation is a sector where human interaction is very common. For this reason, internal costumer satisfaction affects the given services directly. The satisfaction of the working costumer affects both the given services and the work environment. When a controller working in the aerodrome control tower is happy and satisfied with his/her job and he/she gives quality services, as a costumer, the controller working in approach control unit will provide quality service. In the same way, when the controller working in approach control unit works as required, controller in aerodrome control, who is the internal customer of approach control unit, will work safely, orderly and efficiently. By this means, possible dangerous situations and accidents will decrease.

Another factor that affects the performances and satisfaction of internal costumers is reward or promotion. When the workers are rewarded or get promoted by the performances they display, there is an increase in the quality of the services they provide [5].

There is not any reward systems provided for air traffic controllers in Turkey. Controllers that meet some success criteria or have specific experiences get promoted [8].

Air traffic control services are provided by three main units as aerodrome control, approach control and area control. To explain these units and their internal costumers respectively; aerodrome control service, as one of the air traffic control services, is generally provided by two different units, in crowded airports, this service is provided by three different positions. These positions are Tower Control Position, Ground Control Position and Clearance Delivery Position. 
After the aircraft that comes to land on an airport is taken over from Approach Control unit, Tower Controller gives landing clearance with required instructions. While related aircraft lands and leaves the active runway, it is transferred to Ground Control frequency. Since air traffic control services are given by different units, each unit has its own assigned radio frequency. Thanks to different frequencies, conversations on different frequencies do not interfere with each other [8].

The aircraft, which gets ready to take off, contacts clearance delivery position to get permission to engine run-up and atc clearance. When required permissions are given by clearance delivery controller, the aircraft is transferred to ground control position. Ground controller diverts the aircraft to active runway and transfers it to tower control position to get departure clearance. Tower controller in tower control position enables aircraft to take off by giving permission to take off and required information. After the aircraft reaches a specific height or position, tower controller transfers it to approach control unit.

There are different positions in approach control as there are in aerodrome control unit. Additional positions in approach control unit are activated or deactivated by the approval of air traffic control crew chief in accordance with the density of the traffic. Approach control service is given by a controller and an assistant. Additional positions are activated in line with requirements during dense traffic.

Air traffic controllers in different approach sectors-if there are any-are internal customers of each other in approach control. All approach controllers are internal customers of each other among themselves and they are also internal customers of Area and Aerodrome Control units. A mistake caused by any of the controllers working in approach control may affect another controller working in the same unit but different sector. Since all units work coordinately, it is possible to say that all the workers are internal customers of each other [9]. The controllers perform related actions and output of one unit is used as the input of another unit. Therefore, controllers in the unit and different units are the internal customers of each other.

Areas where approach control and tower controls are provided are smaller when compared to the area where area control service is provided. Tower control service is given to the traffic, which is tracked by ground radar or eyes, near the aerodrome. On the other hand, approach service is given in an area which covers one or more airports. As it was described in former parts of the study, area control service is given in a larger area than all these services. A controller working in area control is always in an interaction with approach control and tower in his/her area of responsibility. Therefore, controllers working in area, approach and tower controls are the internal customers of each other. Since area control is also responsible for the order of international traffic, it is also in an interaction with the neighboring countries. When considered from this point of view, area control is the customer of area control service units of neighboring countries. 
Area control is the internal costumer of international neighboring sectors, national neighboring sectors and tower control units which it is in an interaction with in terms of traffic exchange.

The transfer of related traffic between sectors is performed in a specific spot, time between two area controls or at an estimated time when the aircraft goes around the joint control border. Traffic from area control to approach control is performed at a scheduled spot or time. In order to land from approach control to tower control, the approaching aircraft should be around aerodrome. If it can complete the landing by continuing the eye contact with ground and if the flight rules can be applied by seeing the ground, then it can be transferred to tower control. Apart from the situation mentioned above, it is possible for an aircraft to be transferred from approach control to tower control if it is at a specified height, spot or if it lands. A traffic taking off from an aerodrome can be transferred to approach control, if visual flight conditions are presented, if a taking off aircraft gets away from the aerodrome, if that aircraft is at a situation requiring instrument flight rules or at a specified level or a spot. If instrument flight rules are applicable, the aircraft can be transferred to approach control unit as soon as it takes off or reaches at a specified height or a spot. It is also possible to have transfers between different sectors as well as different units. Transfer between different units can be performed at a predetermined spot or height [10].

Whereas different units are internal customers of each other in air traffic services, pilots and airline companies are foreign customers [6]. Pilots and airline companies directly use the services given by the controllers without any intermediaries.

In Turkey, air traffic control services given to the pilots are performed with wirelesses and developed means of communication. Controllers are always in a two-way communication with pilots while providing the service. If there is a contact loss, specific procedures are applied. Controllers track the aircrafts via radars and perform related selections with the help of radar.

Air traffic controllers does not only contact with pilots. Controllers can contact many different units in or outside the airport for the continuity of operations. For instance, controller can receive information about the important events from briefing office or meteorological information form meteorology office. Foreign customers of the controllers providing air traffic control services are pilots. If the pilot receiving a service is affiliated to aviation establishment (Airline Company, training establishments, aircraft manufacturers etc.), he/she is also a foreign customer of aforesaid establishment.

\section{The Determination of Satisfaction of Air Traffic Controllers Working in International Airports in Turkey}

Aviation is a sector which has great effects on countries' economies globally. Therefore, any kind of developments are applied to aviation sector immediately. There has been a deregulation in Turkey with a change in law in 2003, and with this change the numbers of passengers and traffic have been increasing since 
then, especially in domestic flights.

Increasing number of traffic and its density created a competition and new airline companies were established. In parallel with these developments, a lot of developments were experienced in air navigational services, and new airports were established especially in eastern regions.

Increasing number of traffic and newly opened airports also increased the need for air traffic controllers. Coordination between air traffic controllers has become more important with the increase in the number of traffic and airports. A pilot communicates with a lot of controllers during a flight either in domestic routes or in international flights indiscriminatingly, he/she is transferred from a unit to another unit and completes his/her flights.

Because of the coordination performed, the quality of a service given by a controller first affects himself and then the service given by the controller whose area of responsibility is in the related traffic.

\section{Methodology}

In order to measure internal customer satisfaction, the scale presented in the article called INTQUAL-An Internal Measure Of Service Quality And The Link Between Service Quality and Business Performance [11] and parts of the studies with surveys, where INTQUAL was used, related to air traffic control services were analyzed and survey questions were prepared. Since air traffic control services are given by different units, questions special to air traffic control units were added along with adapted questions of INTQUAL survey. Except from the demographic questions, all questions were prepared in accordance with five point Likert scale. There are 51 questions in survey form.

Factor analysis was performed on the study and it was reduced to 4 dimensions. In the phase, to test his hypothesis with these groups, the researcher used Kruskall Wallis test as one of the tests that is not parametric. Kruskall Wallis test compares measurements related to a dependent variable of two or more groups and it is used to test whether there is a significant difference between these two groups.

\section{Results}

In order to test the reliability of survey form used in the study, Cronbach's Alpha reliability test and KMO and Barlett's sphericity tests were applied. Results related to Cronbach's Alpha analysis are shown in Table 1.

Table 1. Cronbach alpha's reliability test results.

\begin{tabular}{|c|c|c|c|}
\hline \multirow{4}{*}{ Cases } & & $\mathbf{N}$ & $\%$ \\
\hline & Valid & 290 & 100.0 \\
\hline & Excluded $^{\mathrm{a}}$ & 0 & 0.0 \\
\hline & Total & 290 & 100.0 \\
\hline \multicolumn{4}{|c|}{ a Listwise deletion based on all variables in the procedure. } \\
\hline \multirow{2}{*}{\multicolumn{2}{|c|}{ Reliability Statistics }} & pha & $\mathrm{N}$ of Items \\
\hline & & & 17 \\
\hline
\end{tabular}


In order to determine whether the sample chosen from research population was wide enough, in other words, if the survey form was applied to sufficient number of participants, KMO (Kaiser Meyer Olkin) test was applied. The result of the test was defined as 0.909 and this value, which is higher than 0.800 , proves that survey was applied to sufficient number of participants. Barlett's Sphericity Test is a test which measures aberration of variance, in other words homogeneity of variances and in this way it reveals whether the study is appropriate for factor analysis. This test was performed to analyze the relationships between variables. As a result of the test, Barlett's Sphericity Test value was determined as 0.000 and it was seen that $\mathrm{p}<0.05$.

\section{Analysis of the Data}

In the first part of survey study, there are questions to measure demographic properties. The survey was applied to controllers working in different units in 3 airports. Obtained data related to applied airports is in Table 2.

Table 2. Obtained data related to applied airports.

\begin{tabular}{cccccc}
\hline & & Frequency & Percent & Valid Percent & Cumulative Percent \\
\hline \multirow{4}{*}{ Valid } & Ankara & 131 & 45.2 & 45.2 & 45.2 \\
& Antalya & 59 & 20.3 & 20.3 & 65.5 \\
& İstanbul & 100 & 34.5 & 34.5 & 100.0 \\
& Total & 290 & 100.0 & 100.0 & \\
\hline
\end{tabular}

\section{Results of Factor Analysis}

Statements used in factor analysis part are listed in Table 3. The eighth statement (while recruiting staff, the organization pays attention to choose employees who believe in the importance of providing flawless service.) was removed because it does not belong to "service quality".

Table 3. Factor analysis statement rotated component matrix*.

\begin{tabular}{|c|c|c|c|c|c|}
\hline & & \multicolumn{4}{|c|}{ COMPONENTS } \\
\hline & & 1 & 2 & 3 & 4 \\
\hline \multirow{3}{*}{$\begin{array}{l}\text { Organization } \\
\text { al practices } \\
\text { and processes }\end{array}$} & $\begin{array}{l}\text { S5 5. Managers in the organization convey the } \\
\text { importance of performing flawless service to } \\
\text { employees in regular intervals. }\end{array}$ & 0.828 & & & \\
\hline & $\begin{array}{l}\text { S6 6. The importance of performing flawless } \\
\text { service is emphasized with means of written } \\
\text { communication (e-mail, pinboard, notice } \\
\text { board) in my organization. }\end{array}$ & 0.776 & & & \\
\hline & $\begin{array}{l}\text { S3 3. A lot of money has been spent to perform } \\
\text { the service in a safe way. }\end{array}$ & 0.595 & & & \\
\hline $\begin{array}{l}\text { Foreign } \\
\text { customers }\end{array}$ & $\begin{array}{l}\text { S15 15. Controllers are always tend to meet the } \\
\text { expectations of pilots more than they demand }\end{array}$ & & 0.812 & & \\
\hline
\end{tabular}




\section{Continued}

\begin{tabular}{|c|c|c|c|c|}
\hline & $\begin{array}{l}\text { S14 } 14 \text {. Controllers are trained to show that } \\
\text { customers of the organization (pilots, airline } \\
\text { companies) are important and valuable for the } \\
\text { organization. }\end{array}$ & 0.797 & & \\
\hline & $\begin{array}{l}\text { S11 11. We as the controllers believe that we try } \\
\text { to provide the expected service of the } \\
\text { customers (of pilots and of airline companies). }\end{array}$ & 0.635 & & \\
\hline & $\begin{array}{l}\text { S16 16. The expectations of pilots and airline } \\
\text { companies from the provided service } \\
\text { correspond to the determined performance of } \\
\text { the organization. }\end{array}$ & 0.623 & & \\
\hline & $\begin{array}{l}\text { S17 17. My organization has positive ideas } \\
\text { about the expectations of the customers (pilots, } \\
\text { airline companies, aviation companies) }\end{array}$ & 0.581 & & \\
\hline \multirow{6}{*}{$\begin{array}{l}\text { Service } \\
\text { quality }\end{array}$} & $\begin{array}{l}\text { S13 13. Major priority for us while working is } \\
\text { to perform the duty safely }\end{array}$ & & 0.762 & \\
\hline & $\begin{array}{l}\text { S1 1. "Performing flawless service" is a focus } \\
\text { objective in the organization I work. }\end{array}$ & & 0.687 & \\
\hline & $\begin{array}{l}\text { S9 9. The aim of the trainings offered in the } \\
\text { organization is to provide a flawless air traffic } \\
\text { control service. }\end{array}$ & & 0.621 & \\
\hline & $\begin{array}{l}\text { S4 } 4 \text {. Employees in the organization } \\
\text { comprehend the importance of performing } \\
\text { flawless service in a safe way. }\end{array}$ & & 0.582 & \\
\hline & $\begin{array}{l}\text { S2 2. Managers in the organization believe that } \\
\text { performing flawless service will increase } \\
\text { productivity. }\end{array}$ & & 0.569 & \\
\hline & $\begin{array}{l}\text { S7 7. "Performing flawless service" is among } \\
\text { the missions of the organization. }\end{array}$ & & 0.503 & \\
\hline \multirow[b]{2}{*}{$\begin{array}{c}\text { Internal } \\
\text { customers }\end{array}$} & $\begin{array}{l}\text { S10 10. There are teams responsible from the } \\
\text { performing of flawless service in different units } \\
\text { (tower, approach, area) in the organization. }\end{array}$ & & & 0.874 \\
\hline & $\begin{array}{l}\text { S12 12. There is a regular communication } \\
\text { between the controllers who provide the service } \\
\text { and the unit that guarantees the performing of } \\
\text { the service. }\end{array}$ & & \multicolumn{2}{|r|}{0.546} \\
\hline
\end{tabular}

Extraction Method: Principal Component Analysis. Rotation Method: Varimax with Kaiser Normalization. a. Rotation converged in 7 iterations.

H1: The opinions about Organizational Application and Processes of the controllers in airport, where the application was performed are similar.

H2: The opinions about Foreign Customers of the controllers in airport, where the application was performed are similar.

H3: The opinions about Service Quality of the controllers in airport, where the application was performed are similar.

H4: The opinions about Internal Customers of the controllers in airport, 
where the application was performed are similar.

All of factors and test statistics are shown in Table 4.

H1: We can not verify the hypothesis at 0.05 significance level because $\mathrm{p}=$ 0.001 and $\mathrm{p}<0.05$.

$\mathrm{H} 2$ : We can verify the hypothesis at 0.05 significance level because $\mathrm{p}=0.319$ and $\mathrm{p}>0.05$.

H3: We can verify the hypothesis at 0.05 significance level because $\mathrm{p}=0.145$ and $\mathrm{p}>0.05$.

H4: We can verify the hypothesis at 0.05 significance level because $p=0.087$ and $\mathrm{p}>0.05$.

Table 4. Ranks of factors.

\begin{tabular}{|c|c|c|c|c|}
\hline \multicolumn{5}{|c|}{ Ranks } \\
\hline & Area & $\mathbf{N}$ & \multicolumn{2}{|c|}{ Mean Rank } \\
\hline \multirow{5}{*}{$\begin{array}{l}\text { Organizational } \\
\text { Application } \\
\text { and } \\
\text { Processes }\end{array}$} & Ankara & 131 & \multicolumn{2}{|c|}{126.24} \\
\hline & & & \multirow{2}{*}{\multicolumn{2}{|c|}{168.43}} \\
\hline & Antalya & 59 & & \\
\hline & İstanbul & 100 & \multicolumn{2}{|c|}{157.20} \\
\hline & Total & 290 & & \\
\hline \multirow{4}{*}{$\begin{array}{l}\text { Foreign } \\
\text { Customers }\end{array}$} & Ankara & 131 & \multicolumn{2}{|c|}{147.91} \\
\hline & Antalya & 59 & \multicolumn{2}{|c|}{131.01} \\
\hline & İstanbul & 100 & \multicolumn{2}{|c|}{150.89} \\
\hline & Total & 290 & & \\
\hline \multirow{4}{*}{$\begin{array}{l}\text { Service } \\
\text { Quality }\end{array}$} & Ankara & 131 & \multicolumn{2}{|c|}{151.66} \\
\hline & Antalya & 59 & \multicolumn{2}{|c|}{154.30} \\
\hline & İstanbul & 100 & \multicolumn{2}{|c|}{132.24} \\
\hline & Total & 290 & & \\
\hline \multirow{4}{*}{$\begin{array}{l}\text { Internal } \\
\text { customers }\end{array}$} & Ankara & 131 & \multicolumn{2}{|c|}{134.01} \\
\hline & Antalya & 59 & \multicolumn{2}{|c|}{160.48} \\
\hline & İstanbul & 100 & \multicolumn{2}{|c|}{151.71} \\
\hline & Total & 290 & & \\
\hline \multicolumn{5}{|c|}{ Test Statistics ${ }^{\mathrm{a}, \mathrm{b}}$} \\
\hline & $\begin{array}{c}\text { Organizational Application } \\
\text { and Processes }\end{array}$ & $\begin{array}{l}\text { Foreign } \\
\text { Customers }\end{array}$ & $\begin{array}{l}\text { Service } \\
\text { Quality }\end{array}$ & $\begin{array}{l}\text { Internal } \\
\text { Services }\end{array}$ \\
\hline Chi-Square & 13.268 & 2.283 & 3.856 & 4.890 \\
\hline df & 2 & 2 & 2 & 2 \\
\hline Asymp. Sig. & 0.001 & 0.319 & 0.145 & 0.087 \\
\hline
\end{tabular}

${ }^{\mathrm{a} K r u s k a l ~ W a l l i s ~ T e s t ; ~}{ }^{\mathrm{b}}$ Grouping Variable: Area.

$\mathrm{H} 1$ hypothesis is not accepted because $\mathrm{p}<0.05$. That is to say air traffic controllers from different aerodromes do not have similar ideas about organizational application and processes. This difference of opinion is clearly caused by An- 
kara Esenboğa Airport. Various statements related to organizational application and processes were given to controllers and it was seen that the answer "I neither agree nor disagree" was given more by the employees from Ankara Esenboğa Airport. Employees from Istanbul and Antalya airports gave the answer "I agree" more. It is possible to say that employees from Esenboğa Airport are less satisfied by organizational application and processes than the other airports.

$\mathrm{H} 2$ hypothesis is accepted because $\mathrm{p}>0.05$. Opinions about foreign customers of controllers from different aerodromes are similar.

$\mathrm{H} 3$ hypothesis is accepted because $\mathrm{p}>0.05$. Opinions about service quality of controllers from different aerodromes are similar.

"Do you have a valid rate now or did you have before" statement: Thinking that the answers of three people are not statistically significant, people saying "I had a rate formerly but now I do not" and "I have a valid rate" were collected under the same title while performing Kruskal-Wallis test. Giving frequencies for controller rate statements in Table 5. Hypothesis tests were given in Table 6.

H1: The opinions about Organizational Application and Processes of controllers according to their rates are similar.

H2: The opinions about Foreign Customers of controllers according to their rates are similar.

H3: The opinions about Service Quality of controllers according to their rates are similar.

H4: The opinions about Internal Customers controllers according to their rates units are similar.

H1: Since $\mathrm{p}=0.002$ and $\mathrm{p}<0.05$ we cannot verify the hypothesis at 0.05 significance level. It is possible to say that the difference is because of the people having a valid rate. People with a valid rate are less satisfied than the people with no valid date in terms of organizational application and processes. If a licensed air traffic controller works in an area control unit, he should work at least for seven months to get a rate. This period may get longer in accordance with the abilities of controller. This means air traffic controllers with a rate are more experienced than air traffic controllers without a rate. The reason why air traffic controllers without a rate are more satisfied with organizational application and processes is that they are less experienced.

$\mathrm{H} 2$ : We can verify the hypothesis at 0.05 significance level because $\mathrm{p}=0.242$ and $p>0.05$. The opinions about organizational application and processes of air

Table 5. Controller rate statements.

\begin{tabular}{|c|c|c|c|c|c|}
\hline & & Frequency & Percent & $\begin{array}{l}\text { Valid } \\
\text { Percent }\end{array}$ & $\begin{array}{l}\text { Cumulative } \\
\text { Percent }\end{array}$ \\
\hline \multirow{4}{*}{ Valid } & I have a valid rate & 272 & 93.8 & 93.8 & 93.8 \\
\hline & $\begin{array}{l}\text { I had a rate formerly but now I } \\
\text { do not }\end{array}$ & 3 & 1.0 & 1.0 & 94.8 \\
\hline & I do not have a rate & 15 & 5.2 & 5.2 & 100.0 \\
\hline & Total & 290 & 100.0 & 100.0 & \\
\hline
\end{tabular}


Table 6. Hypothesis test results by controller rate.

\begin{tabular}{|c|c|c|c|c|}
\hline \multicolumn{5}{|c|}{ Ranks } \\
\hline & \multicolumn{2}{|c|}{$\begin{array}{l}\text { D2-Do you have a valid rate now } \\
\text { or did you have before? }\end{array}$} & $\mathbf{N}$ & Mean Rank \\
\hline \multirow{3}{*}{$\begin{array}{l}\text { Organizational } \\
\text { Application and } \\
\text { Processes }\end{array}$} & \multicolumn{2}{|l|}{ I have a valid rate } & 275 & 141.54 \\
\hline & \multicolumn{2}{|l|}{ I do not have a rate } & 15 & 205.39 \\
\hline & \multicolumn{2}{|l|}{ Total } & \multicolumn{2}{|l|}{290} \\
\hline \multirow{3}{*}{$\begin{array}{l}\text { Foreign } \\
\text { Customers }\end{array}$} & \multicolumn{2}{|l|}{ I have a valid rate } & 275 & 144.02 \\
\hline & \multicolumn{2}{|l|}{ I do not have a rate } & 15 & 167.89 \\
\hline & \multicolumn{2}{|l|}{ Total } & \multicolumn{2}{|l|}{290} \\
\hline \multirow{3}{*}{ Service Quality } & \multicolumn{2}{|l|}{ I have a valid rate } & 275 & 146.29 \\
\hline & \multicolumn{2}{|l|}{ I do not have a rate } & 15 & 133.61 \\
\hline & \multicolumn{2}{|l|}{ Total } & \multicolumn{2}{|l|}{290} \\
\hline \multirow{3}{*}{$\begin{array}{l}\text { Internal } \\
\text { Customers }\end{array}$} & \multicolumn{2}{|l|}{ I have a valid rate } & 275 & 144.82 \\
\hline & \multicolumn{2}{|l|}{ I do not have a rate } & 15 & 155.72 \\
\hline & \multicolumn{2}{|l|}{ Total } & \multicolumn{2}{|l|}{290} \\
\hline \multicolumn{5}{|c|}{ Test Statistics ${ }^{\mathrm{a}, \mathrm{b}}$} \\
\hline & $\begin{array}{l}\text { Organizational Application } \\
\text { and Processes }\end{array}$ & $\begin{array}{l}\text { Foreign } \\
\text { Customers }\end{array}$ & $\begin{array}{l}\text { Service } \\
\text { Quality }\end{array}$ & $\begin{array}{l}\text { Internal } \\
\text { Customers }\end{array}$ \\
\hline Chi-Square & 9.788 & 1.368 & 0.386 & 0.285 \\
\hline df & 1 & 1 & 1 & 1 \\
\hline Asymp. Sig. & 0.002 & 0.242 & 0.535 & 0.593 \\
\hline
\end{tabular}

${ }^{a}$ Kruskal Wallis Test; ${ }^{\mathrm{b}}$ Grouping Variable: D2 Do you have a valid rate now or did you have before?

traffic controllers are similar.

H3: We can verify the hypothesis at 0.05 significance level because $\mathrm{p}=0.535$ and $p>0.05$. The opinions about service quality of air traffic controllers are similar.

H4: We can verify the hypothesis at 0.05 significance level because $p=0.593$ and $p>0.05$. The opinions about internal customers of air traffic controllers with or without a rate are similar.

"For which unit are you working now" statement: Giving frequencies for controllers working positions statements in Table 7. Hypothesis tests were given in Table 8.

Table 7. Controllers working positions.

\begin{tabular}{cccccc}
\hline & & Frequency & Percent & Valid Percent & Cumulative Percent \\
\hline \multirow{4}{*}{ Valid } & Tower Control & 87 & 30.0 & 30.0 & 30.0 \\
& Approach Control & 94 & 32.4 & 32.4 & 62.4 \\
& Area Control & 109 & 37.6 & 37.6 & 100.0 \\
& Total & 290 & 100.0 & 100.0 & \\
\hline
\end{tabular}


Table 8. Hypothesis test results by working positions.

\begin{tabular}{|c|c|c|c|c|}
\hline \multicolumn{5}{|c|}{ Ranks } \\
\hline & & \multicolumn{2}{|r|}{$\mathbf{N}$} & Mean Rank \\
\hline \multirow{4}{*}{$\begin{array}{l}\text { Organizational } \\
\text { Application and } \\
\text { Processes }\end{array}$} & Tower Control & \multicolumn{2}{|r|}{87} & 160.05 \\
\hline & Approach Control & \multicolumn{2}{|r|}{94} & 163.66 \\
\hline & Area Control & \multicolumn{2}{|r|}{109} & 118.22 \\
\hline & Total & \multicolumn{2}{|r|}{290} & \\
\hline \multirow{4}{*}{ Foreign Customers } & Tower Control & \multicolumn{2}{|r|}{87} & 147.42 \\
\hline & Approach Control & \multicolumn{2}{|r|}{94} & 142.97 \\
\hline & Area Control & \multicolumn{2}{|r|}{109} & 146.15 \\
\hline & Total & \multicolumn{2}{|r|}{290} & \\
\hline \multirow{4}{*}{ Service Quality } & Tower Control & \multicolumn{2}{|r|}{87} & 156.81 \\
\hline & Approach Control & \multicolumn{2}{|r|}{94} & 139.68 \\
\hline & Area Control & \multicolumn{2}{|r|}{109} & 141.49 \\
\hline & Total & \multicolumn{2}{|r|}{290} & \\
\hline \multirow{4}{*}{ Internal Customers } & Tower Control & \multicolumn{2}{|r|}{87} & 167.26 \\
\hline & Approach Control & \multicolumn{2}{|r|}{94} & 140.94 \\
\hline & Area Control & \multicolumn{2}{|r|}{109} & 132.07 \\
\hline & Total & \multicolumn{2}{|r|}{290} & \\
\hline \multicolumn{5}{|c|}{ Test Statistics ${ }^{\mathrm{a}, \mathrm{b}}$} \\
\hline & $\begin{array}{c}\text { Organizational } \\
\text { Application and Processes }\end{array}$ & $\begin{array}{l}\text { Foreign } \\
\text { Customers }\end{array}$ & $\begin{array}{l}\text { Service } \\
\text { Quality }\end{array}$ & $\begin{array}{l}\text { Internal } \\
\text { Customers }\end{array}$ \\
\hline Chi-Square & 18.558 & 0.138 & 2.284 & 8.931 \\
\hline df & 2 & 2 & 2 & 2 \\
\hline Asymp. Sig. & 0.000 & 0.933 & 0.319 & 0.011 \\
\hline
\end{tabular}

${ }^{\mathrm{a}}$ Kruskal Wallis Test; ${ }^{\mathrm{b}}$ Grouping Variable: D3 For which unit are you working now?

H1: The opinions about Organizational Application and Processes of air traffic controllers in different units are similar.

H2: The opinions about Foreign Customers of air traffic controllers in different units are similar.

H3: The opinions about Service Quality of air traffic controllers in different units are similar.

H4: The opinions about Internal Customers air traffic controllers in different units are similar.

H1: We can not verify the hypothesis at 0.05 significance level because $\mathrm{p}=$ 0.000 and $p<0.05$. The opinions about organizational application and processes of air traffic controllers from different units are not similar. The difference is because of the area control.

Employees from area control do not agree with the related statements when compared to the other units. This situation could be an indicator of need of 
some recoveries in area control units. This is because area control provides service in a larger geography and the number of units provided with the service is higher than the other units.

$\mathrm{H} 2$ : We can verify the hypothesis at 0.05 significance level because $\mathrm{p}=0.242$ and $\mathrm{p}>0.05$. Opinions about foreign customers of employees from different units are similar.

$\mathrm{H} 3$ : We can verify the hypothesis at 0.05 significance level because $p=0.535$ and $\mathrm{p}>0.05$. Opinions about service quality of employees from different units are similar.

H4: We can not verify the hypothesis at 0.05 significance level because $\mathrm{p}=$ 0.011 and $p<0.05$. It is possible to say that the difference is because of area control. Air traffic controllers from area control are less agreed on the statements related to internal customers when compared to other units. This situation is because the employees from area control are not satisfied with internal customers.

"What is your age group?" statement: Giving frequencies for controller age groups statements in Table 9. Hypothesis tests were given in Table 10.

H1: The opinions about Organizational Application and Processes of air traffic controllers in different age groups are similar.

$\mathrm{H} 2$ : The opinions about Foreign Customers of air traffic controllers in different age groups are similar.

H3: The opinions about Service Quality of air traffic controllers in different age groups are similar.

H4: The opinions about Internal Customers air traffic controllers in different age groups are similar.

$\mathrm{H} 1$ : We can verify the hypothesis at 0.05 significance level because $p=0.836$ and $\mathrm{p}>0.05$.

$\mathrm{H} 2$ : we can not verify the hypothesis at 0.05 significance level because $\mathrm{p}=0.05$ and $\mathrm{p}<0.05$. The difference is because of the people of 49 years old and older. Since 49-year-old and older controllers have a command of the job, they can understand the expectations and demands of foreign and internal customers better, and therefore they agree more on the statements than the other employees.

H3: We can verify the hypothesis at 0.05 significance level because $p=0.219$

Table 9. Controller age groups.

\begin{tabular}{cccccc}
\hline & Frequency & Percent & Valid Percent & Cumulative Percent \\
\hline & $18-28$ & 61 & 21.0 & 21.0 & 21.0 \\
& $29-38$ & 130 & 44.8 & 44.8 & 65.9 \\
\multirow{4}{*}{ Valid } & $39-48$ & 73 & 25.2 & 25.2 & 91.0 \\
& $49-60$ & 25 & 8.6 & 8.6 & 99.7 \\
& 61 and older & 1 & 0.3 & 0.3 & 100.0 \\
& Total & 290 & 100.0 & 100.0 & \\
\hline
\end{tabular}


Table 10. Hypothesis test results by age groups.

\begin{tabular}{|c|c|c|c|c|}
\hline \multicolumn{5}{|c|}{ Ranks } \\
\hline & \multicolumn{2}{|c|}{ D4-What is your age group? } & $\mathbf{N}$ & Mean Rank \\
\hline \multirow{7}{*}{$\begin{array}{l}\text { Organizational } \\
\text { Application and } \\
\text { Processes }\end{array}$} & \multicolumn{2}{|l|}{$18-28$} & 61 & 155.71 \\
\hline & \multicolumn{2}{|l|}{$29-38$} & 130 & 141.53 \\
\hline & \multicolumn{2}{|l|}{$39-48$} & 73 & 146.82 \\
\hline & \multirow{2}{*}{\multicolumn{2}{|c|}{$49-60$}} & & \\
\hline & & & 25 & 137.48 \\
\hline & \multicolumn{2}{|l|}{61 and older } & 1 & 143.00 \\
\hline & \multicolumn{2}{|l|}{ Total } & 290 & \\
\hline \multirow{6}{*}{ Foreign Customers } & \multicolumn{2}{|l|}{$18-28$} & 61 & 157.88 \\
\hline & \multicolumn{2}{|l|}{$29-38$} & 130 & 135.77 \\
\hline & \multicolumn{2}{|l|}{$39-48$} & 73 & 138.33 \\
\hline & \multicolumn{2}{|l|}{$49-60$} & 25 & 184.60 \\
\hline & \multicolumn{2}{|l|}{61 and older } & 1 & 202.00 \\
\hline & \multicolumn{2}{|l|}{ Total } & 290 & \\
\hline \multirow{6}{*}{ Service Quality } & \multicolumn{2}{|l|}{$18-28$} & 61 & 128.06 \\
\hline & \multicolumn{2}{|l|}{$29-38$} & 130 & 144.08 \\
\hline & \multicolumn{2}{|l|}{$39-48$} & 73 & 158.14 \\
\hline & \multicolumn{2}{|l|}{$49-60$} & 25 & 155.04 \\
\hline & \multicolumn{2}{|l|}{61 and older } & 1 & 233.00 \\
\hline & \multicolumn{2}{|l|}{ Total } & 290 & \\
\hline & \multicolumn{2}{|l|}{$18-28$} & 61 & 152.70 \\
\hline & \multicolumn{2}{|l|}{$29-38$} & 130 & 129.60 \\
\hline Internal & \multicolumn{2}{|l|}{$39-48$} & 73 & 152.29 \\
\hline Customers & \multicolumn{2}{|l|}{$49-60$} & 25 & 192.76 \\
\hline & \multicolumn{2}{|l|}{61 and older } & 1 & 97.00 \\
\hline & \multicolumn{2}{|l|}{ Total } & 290 & \\
\hline \multicolumn{5}{|c|}{ Test Statistics ${ }^{a, b}$} \\
\hline & $\begin{array}{l}\text { Organizational Application } \\
\text { and Processes }\end{array}$ & $\begin{array}{c}\text { Foreign } \\
\text { Customers }\end{array}$ & $\begin{array}{l}\text { Service } \\
\text { Quality }\end{array}$ & $\begin{array}{c}\text { Internal } \\
\text { Customers }\end{array}$ \\
\hline Chi-Square & 1.444 & 9.503 & 5.746 & 13.878 \\
\hline $\mathrm{df}$ & 4 & 4 & 4 & 4 \\
\hline Asymp. Sig. & 0.836 & 0.050 & 0.219 & 0.008 \\
\hline
\end{tabular}

${ }^{\mathrm{a}}$ Kruskal Wallis Test; ${ }^{\mathrm{b}}$ Grouping Variable: D4 What is your age group?

and $\mathrm{p}>0.05$.

$\mathrm{H} 4$ : We can not verify the hypothesis at 0.05 significance level. It is possible to say that the difference is because of the people of 49 years old and older. We can say that 49-year-old and older controllers are more satisfied with internal costumers than the other employees.

"What is your gender?" statement: Giving frequencies for controllers' genders statements in Table 11. Hypothesis tests were given in Table 12. 
Table 11. Controller genders.

\begin{tabular}{cccccc}
\hline & & Frequency & Percent & Valid Percent & Cumulative Percent \\
\hline \multirow{3}{*}{ Valid } & Male & 116 & 40.0 & 40.0 & 40.0 \\
& Female & 174 & 60.0 & 60.0 & 60.0 \\
& & 290 & 100.0 & 100.0 & 100.0 \\
\hline
\end{tabular}

H1: The opinions about Organizational Application and Processes of air traffic controllers by gender are similar.

H2: The opinions about Foreign Customers of air traffic controllers by gender are similar.

H3: The opinions about Service Quality of air traffic controllers by gender are similar.

H4: The opinions about Internal Customers air traffic controllers by gender are similar.

Table 12. Hypothesis test results by genders.

\begin{tabular}{|c|c|c|c|c|}
\hline \multicolumn{5}{|c|}{ Ranks } \\
\hline & \multicolumn{2}{|l|}{ D5-What is your gender? } & $\mathbf{N}$ & Mean Rank \\
\hline Occupational & \multicolumn{2}{|l|}{ Female } & 116 & 147.54 \\
\hline Application and & \multicolumn{2}{|l|}{ Male } & 174 & 144.14 \\
\hline Processes & \multicolumn{2}{|l|}{ Total } & 290 & \\
\hline \multirow{3}{*}{ Foreign Customers } & Female & & 116 & 149.47 \\
\hline & Male & & 174 & 142.86 \\
\hline & Total & & 290 & \\
\hline \multirow{3}{*}{ Service Quality } & Female & & 116 & 153.13 \\
\hline & Male & & 174 & 140.41 \\
\hline & Total & & 290 & \\
\hline \multirow{3}{*}{ Internal Customers } & Female & & 116 & 128.66 \\
\hline & Male & & 174 & 156.73 \\
\hline & Total & & 290 & \\
\hline \multicolumn{5}{|c|}{ Test Statistics ${ }^{\mathrm{a}, \mathrm{b}}$} \\
\hline & $\begin{array}{c}\text { Occupational Application } \\
\text { and Processes }\end{array}$ & $\begin{array}{c}\text { Foreign } \\
\text { Customers }\end{array}$ & $\begin{array}{l}\text { Service } \\
\text { Quality }\end{array}$ & $\begin{array}{c}\text { Internal } \\
\text { Customers }\end{array}$ \\
\hline Chi-Square & 0.115 & 0.432 & 1.600 & 7.801 \\
\hline df & 1 & 1 & 1 & 1 \\
\hline Asymp. Sig. & 0.735 & 0.511 & 0.206 & 0.005 \\
\hline
\end{tabular}

${ }^{\mathrm{a}}$ Kruskal Wallis Test; ${ }^{\mathrm{b}}$ Grouping Variable: D5 What is your gender?

H1: We can verify the hypothesis at 0.05 significance level because $\mathrm{p}=0.735$ and $\mathrm{p}>0.05$.

$\mathrm{H} 2$ : We can verify the hypothesis at 0.05 significance level because $\mathrm{p}=0.511$ and $\mathrm{p}>0.05$. 
H3: We can verify the hypothesis at 0.05 significance level because $p=0.206$ and $\mathrm{p}>0.05$.

H4: We can not verify the hypothesis at 0.05 significance level because $\mathrm{p}=$ 0.005 and $\mathrm{p}>0.05$.

"How long have you been working as an air traffic controller?" statement: Giving frequencies for controller working years statements in Table 13. Hypothesis tests were given in Table 14.

Table 13. Controller working years.

\begin{tabular}{cccccc}
\hline & & Frequency & Percent & Valid Percent & C. Percent \\
\hline & $0-2$ years & 46 & 15.9 & 15.9 & 15.9 \\
& $3-5$ years & 52 & 17.9 & 17.9 & 33.8 \\
Valid & 6 - 9 years & 54 & 18.6 & 18.6 & 52.4 \\
& 10 years and more & 138 & 47.6 & 47.6 & 100.0 \\
& Total & 290 & 100.0 & 100.0 & \\
\hline
\end{tabular}

H1: The opinions about Organizational Application and Processes of air traffic controllers by working year are similar.

H2: The opinions about Foreign Customers of air traffic controllers by working year are similar.

H3: The opinions about Service Quality of air traffic controllers by working year are similar.

H4: The opinions about Internal Customers air traffic controllers by working year are similar.

Table 14. Hypothesis test results by working years.

\begin{tabular}{|c|c|c|c|}
\hline \multicolumn{4}{|c|}{ Ranks } \\
\hline & $\begin{array}{c}\text { D6-How long have you been working as } \\
\text { an air traffic controller? }\end{array}$ & $\mathbf{N}$ & Mean Rank \\
\hline \multirow{5}{*}{$\begin{array}{l}\text { Occupational } \\
\text { Application and } \\
\text { Processes }\end{array}$} & $0-2$ years & 46 & 166.16 \\
\hline & $3-5$ years & 52 & 141.78 \\
\hline & $6-9$ years & 54 & 129.43 \\
\hline & 10 years and more & 138 & 146.30 \\
\hline & Total & 290 & \\
\hline \multirow{5}{*}{ Foreign Customers } & $0-2$ years & 46 & 165.75 \\
\hline & $3-5$ years & 52 & 137.36 \\
\hline & $6-9$ years & 54 & 135.46 \\
\hline & 10 years and more & 138 & 145.75 \\
\hline & Total & 290 & \\
\hline \multirow{3}{*}{ Service Quality } & $0-2$ years & 46 & 136.82 \\
\hline & $3-5$ years & 52 & 124.72 \\
\hline & 6 - 9 years & 54 & 148.94 \\
\hline
\end{tabular}


Continued

\begin{tabular}{|c|c|c|c|c|}
\hline & \multicolumn{2}{|c|}{10 years and more } & 138 & 154.88 \\
\hline & \multicolumn{2}{|l|}{ Total } & 290 & \\
\hline \multirow{5}{*}{ Internal Customers } & \multicolumn{2}{|c|}{0 - 2 years } & 46 & 150.08 \\
\hline & \multicolumn{2}{|l|}{3 - 5 years } & 52 & 136.43 \\
\hline & \multicolumn{2}{|c|}{$6-9$ years } & 54 & 129.39 \\
\hline & \multicolumn{2}{|c|}{10 years and more } & 138 & 153.70 \\
\hline & \multicolumn{2}{|l|}{ Total } & 290 & \\
\hline \multicolumn{5}{|c|}{ Test Statistics ${ }^{\mathrm{a}, \mathrm{b}}$} \\
\hline & $\begin{array}{l}\text { Occupational Application } \\
\text { and Processes }\end{array}$ & $\begin{array}{l}\text { Foreign } \\
\text { Customers }\end{array}$ & $\begin{array}{l}\text { Service } \\
\text { Quality }\end{array}$ & $\begin{array}{c}\text { Internal } \\
\text { Customers }\end{array}$ \\
\hline Chi-Square & 4.892 & 3.947 & 5.502 & 4.056 \\
\hline $\mathrm{df}$ & 3 & 3 & 3 & 3 \\
\hline Asymp. Sig. & 0.180 & 0.267 & 0.138 & 0.255 \\
\hline
\end{tabular}

${ }^{\mathrm{a}}$ Kruskal Wallis Test; ${ }^{\mathrm{b}}$ Grouping Variable: D6 How long have you been working as an air traffic controller?

H1: We can verify the hypothesis at 0.05 significance level because $\mathrm{p}=0.180$ and $\mathrm{p}>0.05$.

$\mathrm{H} 2$ : We can verify the hypothesis at 0.05 significance level because $\mathrm{p}=0.267$ and $\mathrm{p}>0.05$.

H3: We can verify the hypothesis at 0.05 significance level because $p=0.138$ and $\mathrm{p}>0.05$.

H4: We can not verify the hypothesis at 0.05 significance level because $\mathrm{p}=$ 0.255 and $\mathrm{p}>0.05$.

Opinions of air traffic controllers by working years are similar.

"How long have you been working in your current unit?" statement: Giving frequencies for controller working years in units statements in Table 15. Hypothesis tests were given in Table 16.

Table 15. Controller working years in units.

\begin{tabular}{|c|c|c|c|c|c|}
\hline & & Frequency & Percent & Valid Percent & Cumulative Percent \\
\hline \multirow{5}{*}{ Valid } & 0 - 2 years & 75 & 25.9 & 25.9 & 25.9 \\
\hline & $3-5$ years & 55 & 19.0 & 19.0 & 44.8 \\
\hline & $6-9$ years & 36 & 12.4 & 12.4 & 57.2 \\
\hline & 10 years and more & 124 & 42.8 & 42.8 & 100.0 \\
\hline & Total & 290 & 100.0 & 100.0 & \\
\hline
\end{tabular}

H1: In line with their experience in the unit, the opinions about Organizational Application and Processes of air traffic controllers are similar.

H2: In line with their experience in the unit, the opinions about Foreign Customers of air traffic controllers are similar. 
H3: In line with their experience in the unit, the opinions about Service Quality of air traffic controllers are similar.

H4: In line with their experience in the unit, the opinions about Internal Customers air traffic controllers are similar.

Table 16. Hypothesis test results by working years in units.

\begin{tabular}{|c|c|c|c|c|}
\hline \multicolumn{5}{|c|}{ Ranks } \\
\hline & $\begin{array}{l}\text { D7-How long have you } b \\
\text { working in your current } u\end{array}$ & & $\mathbf{N}$ & Mean Rank \\
\hline \multirow{5}{*}{$\begin{array}{l}\text { Occupational } \\
\text { Application } \\
\text { and Processes }\end{array}$} & $0-2$ years & & 75 & 156.95 \\
\hline & 3 - 5 years & & 55 & 129.62 \\
\hline & 6 - 9 years & & 36 & 137.25 \\
\hline & 10 years and more & & 124 & 148.02 \\
\hline & Total & & 290 & \\
\hline \multirow{5}{*}{$\begin{array}{c}\text { Foreign } \\
\text { Customers }\end{array}$} & $0-2$ years & & 75 & 157.52 \\
\hline & $3-5$ years & & 55 & 124.22 \\
\hline & $6-9$ years & & 36 & 141.00 \\
\hline & 10 years and more & & 124 & 148.98 \\
\hline & Total & & 290 & \\
\hline \multirow{5}{*}{$\begin{array}{l}\text { Service } \\
\text { Quality }\end{array}$} & $0-2$ years & & 75 & 137.09 \\
\hline & $3-5$ years & & 55 & 127.33 \\
\hline & $6-9$ years & & 36 & 151.81 \\
\hline & 10 years and more & & 124 & 156.81 \\
\hline & Total & & 290 & \\
\hline \multirow{5}{*}{$\begin{array}{c}\text { Internal } \\
\text { Customers }\end{array}$} & $0-2$ years & & 75 & 152.77 \\
\hline & 3 - 5 years & & 55 & 120.87 \\
\hline & 6 - 9 years & & 36 & 126.53 \\
\hline & 10 years and more & & 124 & 157.53 \\
\hline & Total & & 290 & \\
\hline \multicolumn{5}{|c|}{ Test Statistics ${ }^{\mathrm{a}, \mathrm{b}}$} \\
\hline & $\begin{array}{c}\text { Organizational } \\
\text { Application and Processes }\end{array}$ & $\begin{array}{c}\text { Foreign } \\
\text { Customers }\end{array}$ & Service Quality & $\begin{array}{c}\text { Internal } \\
\text { Costumers }\end{array}$ \\
\hline Chi-Square & 3.830 & 5.400 & 5.797 & 9.703 \\
\hline df & 3 & 3 & 3 & 3 \\
\hline Asymp. Sig. & 0.280 & 0.145 & 0.122 & 0.021 \\
\hline
\end{tabular}

${ }^{\mathrm{a}}$ Kruskal Wallis Test; ${ }^{\mathrm{b}}$ Grouping Variable: D7 How long have you been working in your current unit?

H1: We can verify the hypothesis at 0.05 significance level because $\mathrm{p}=0.280$ and $\mathrm{p}>0.05$.

$\mathrm{H} 2$ : We can verify the hypothesis at 0.05 significance level because $\mathrm{p}=0.145$ and $\mathrm{p}>0.05$. 
H3: We can verify the hypothesis at 0.05 significance level because $p=0.122$ and $\mathrm{p}>0.05$.

H4: We can not verify the hypothesis at 0.05 significance level because $\mathrm{p}=$ 0.021 and $\mathrm{p}<0.05$.

The difference is caused by the employees working between $0-2$ years and 10 years and older.

"Where did you get your air traffic control training?" statement: Giving frequencies for controller education institutions statements in Table 17. Hypothesis tests were given in Table 18.

Table 17. Controller education institutions.

\begin{tabular}{cccccc}
\hline & & Frequency & Percent & $\begin{array}{c}\text { Valid } \\
\text { Percent }\end{array}$ & $\begin{array}{c}\text { Cumulative } \\
\text { Percent }\end{array}$ \\
\hline \multirow{3}{*}{ Valid } & Anadolu University & 37 & 12.8 & 12.8 & 12.8 \\
& State Airports Administration & 253 & 87.2 & 87.2 & 100.0 \\
& Total & 290 & 100.0 & 100.0 & \\
\hline
\end{tabular}

Table 18. Hypothesis test results by controller education institutions.

\begin{tabular}{|c|c|c|c|c|}
\hline \multicolumn{5}{|c|}{ Ranks } \\
\hline \multicolumn{3}{|c|}{$\begin{array}{l}\text { D8-Where did you get your air } \\
\text { traffic control training? }\end{array}$} & $\mathbf{N}$ & Mean Rank \\
\hline \multirow{3}{*}{$\begin{array}{l}\text { Occupational } \\
\text { Application and } \\
\text { Processes }\end{array}$} & \multicolumn{2}{|l|}{ Anadolu University } & 37 & 132.45 \\
\hline & \multicolumn{2}{|c|}{ State Airports Administration } & 253 & 147.41 \\
\hline & & 290 & \\
\hline \multirow{3}{*}{$\begin{array}{c}\text { Foreign } \\
\text { Customers }\end{array}$} & \multicolumn{2}{|l|}{ Anadolu University } & 37 & 143.23 \\
\hline & \multicolumn{2}{|c|}{ State Airports Administration } & 253 & 145.83 \\
\hline & \multicolumn{2}{|l|}{ Total } & 290 & \\
\hline \multirow{3}{*}{$\begin{array}{l}\text { Service } \\
\text { Quality }\end{array}$} & \multicolumn{2}{|l|}{ Anadolu University } & 37 & 140.12 \\
\hline & \multicolumn{2}{|c|}{ State Airports Administration } & 253 & 146.29 \\
\hline & \multicolumn{2}{|l|}{ Total } & 290 & \\
\hline \multirow{3}{*}{$\begin{array}{c}\text { Internal } \\
\text { Customers }\end{array}$} & \multicolumn{2}{|l|}{ Anadolu University } & 37 & 163.26 \\
\hline & \multicolumn{2}{|c|}{ State Airports Administration } & 253 & 142.90 \\
\hline & \multicolumn{2}{|l|}{ Total } & 290 & \\
\hline \multicolumn{5}{|c|}{ Test Statistics ${ }^{\mathrm{a}, \mathrm{b}}$} \\
\hline & $\begin{array}{c}\text { Organizational } \\
\text { Application and Processes }\end{array}$ & $\begin{array}{c}\text { Foreign } \\
\text { Customers }\end{array}$ & $\begin{array}{l}\text { Service } \\
\text { Quality }\end{array}$ & $\begin{array}{c}\text { Internal } \\
\text { Costumers }\end{array}$ \\
\hline Chi-Square & 1.028 & 0.031 & 0.174 & 1.902 \\
\hline df & 1 & 1 & 1 & 1 \\
\hline Asymp. Sig. & 0.311 & 0.860 & 0.676 & 0.168 \\
\hline
\end{tabular}

${ }^{\mathrm{a}}$ Kruskal Wallis Test; ${ }^{\mathrm{b}}$ Grouping Variable: D8 Where did you get your air traffic control training? 
H1: The opinions about Organizational Application and Processes of air traffic controllers who were trained in different institutions are similar.

H2: The opinions about Foreign Customers of air traffic controllers who were trained in different institutions are similar.

H3: The opinions about Service Quality of air traffic controllers who were trained in different institutions are similar.

H4: The opinions about Internal Customers air traffic controllers who were trained in different institutions are similar.

H1: We can verify the hypothesis at 0.05 significance level because $p=0.311$ and $\mathrm{p}>0.05$.

$\mathrm{H} 2$ : We can verify the hypothesis at 0.05 significance level because $p=0.860$ and $\mathrm{p}>0.05$.

H3: We can verify the hypothesis at 0.05 significance level because $p=0.676$ and $\mathrm{p}>0.05$.

H4: We can verify the hypothesis at 0.05 significance level because $p=0.168$ and $\mathrm{p}>0.05$.

The opinions of all the controllers are similar without discriminating the training institution.

\section{Conclusions}

While providing air traffic control services, sectors or units can be activated depending on the density. In aerodromes which are not very crowded, air traffic control service is given by maximum two controllers working in a tower near the aerodrome. In this kind of aerodromes, approach control service is generally provided by area control units. Aerodromes operating in this way, communication and coordination between controllers as internal customers are quite low. Therefore, international aerodromes, where coordination is very dense, are included in the study.

There are 36 airports which can be used internationally when needed in Turkey. There are 52 airports where air traffic controllers work. Among these airports, İstanbul Atatürk Airport and Ankara Esenboğa Airport were chosen to be the airports where survey is going to be applied, because they both have all units, enough number of air traffic controllers for survey population, and also Turkish space is divided into two sections [12] (FIR-Commercial traffic in Istanbul and Ankara FIRs is controlled by units in İstanbul Atatürk Airport and Ankara Esenboğa Airport).

As of the date when the study was carried out, the number of air traffic controllers working in Istanbul Atatürk Airport is 144 and in Ankara Esenboğa Airport is 196. The population of survey was accepted as 340. Antalya airport was included in the study because area control service is given from a different location, Ankara Esenboğa Airport.

People and computer automation are commonly used while providing air traffic control services today. No matter how developed the technology is, human factors are always on the foreground. This situation could easily be unders- 
tood that although there are a lot of developments in technology, most of the aviation accidents are caused by human mistakes.

The role of air traffic controllers in traffic flow is very important. The satisfaction of the air traffic controllers, who work in such an environment requiring responsibility, from other air traffic controller has become the subject of this research. Air traffic controllers work simultaneously due to different units. A mistake or a delay performed by a controller may affect the other controller working in the following sector. A mistake made at any moment of the flight may cause a chain reaction and affect all the stages until the cutting of the engine. Therefore, working completely flawless of an air traffic controller may not mean anything for this process. All unit employees need to work flawlessly. Therefore, the satisfaction of air traffic controllers towards each other and their opinions about the institutions at work are analyzed. Findings below are attained as a result of the study carried out.

- Air traffic controllers in Ankara Esenboğa airport less satisfied with the organizational application and processes when compared to other airports. Controllers believe that managers in the institution do not work efficiently and enough about providing flawless service.

- Controllers provide expected service to the customers without differentiating aerodrome. It is because air traffic control service does not change depending on the conditions and it is provided to all demanding pilots within the rules.

- Various statements were addressed to the controllers about service quality. While providing air traffic control service, primarily to perform it safely, then in an organized and quick way. Controllers usually agree with the statements. However, among these air traffic controllers who express their opinions, controllers working in area control are less agreed with the statements when compared to other employees from different units. According to these results, when compared to employees working in other units, air traffic controllers working in area control unit think that necessary importance is not given to service quality.

- When compared to air traffic controllers working in other units, air traffic controllers working in tower control are thought not to be trained about paying attention to the expectations of foreign customers of their organization.

- It is thought that necessary studies related to flawless service performance are not enough in approach and area controls.

Suggestions for findings obtained as a result of the study are listed below:

- Air traffic control equipment develop in line with technology, in order air traffic controllers to develop in parallel with this development in technology, internal costumer satisfaction should be increased.

- Teams, responsible for the control of whether letters of agreement signed between units are followed or not, should be established.

- Controllers should report the problems they experienced to their unit chiefs, chiefs from different units should consult each other regularly. 
- Controllers should be sure that necessary separation minima are provided before transferring the traffic to the other units.

- Controllers should be sure that the aircraft is at the determined position stated in letter of agreement.

- The organization should take necessary precautions for controllers to provide same quality service.

Air traffic controllers should solve their problems experienced with internal customers instantly. However, air traffic controllers have to think about their colleagues' satisfaction to provide a more productive working environment and an air space. As it can be understood from the results obtained from the study, the opinions of each air traffic controller could be different. An occupation which cannot accept any faults does not have the opportunity to tolerate these kinds of differences. Therefore, to have internal customer satisfaction should be a business culture rather than a necessity.

Air traffic controllers should not be left alone while solving the problems related to internal customers. Controller can find a temporary solution to the problem in his working hours. Since this solution is not permanent, it can cause irreparable damages in another time. Therefore, the organization which is responsible from providing air traffic controller services should interview and conduct surveys for air traffic controllers about the experienced problems and should take the necessary precautions.

Organizations, which train air traffic controllers, should convey the necessities of the occupation to the applicant while recruiting controllers and should be careful about their choice of appropriate applicant.

\section{References}

[1] Değermen, A. (2006) Hizmet Ürünlerinde Kalite, Müşteri Tatmini ve Sadakati (Hizmet Kalitesi ile Müşteri Sadakatinin Sağlanması ve GSM Sektöründe Bir Uygulama). Türkmen Kitabevi, İstanbul.

[2] Çatı, K., Koçoğlu, C.M. and Gelibolu, L. (2010) Müşteri Beklentileri ile Müşteri Sadakati Arasındaki ilişki: Beş Yıldızlı Bir Otel Örnegì. Çukurova Üniversitesi Sosyal Bilimler Enstitüsü Dergisi, 19-1, 429-446.

[3] Belet, A. (2007) Müşteri Kazanma Teknikleri. Akis Kitap, İstanbul.

[4] Eroğlu, E. (2005) Müşteri Memnuniyeti Ölçüm Modeli. İ.Ü. İşletme Fakültesi İşletme Dergisi, 34-1, 7-25.

[5] Dökmen, T. (2003) Havayolu işletmelerinde müşteri tatmini ve iş gören müşteri karşılaşmalarının müşteri tatmini üzerindeki etkisi. PhD Dissertation, Anadolu University, Eskişehir, 48-63.

[6] Çınar, E. (2010) Hava Trafik Hizmetlerinde Algılanan Hizmet Kalitesi. PhD Dissertation, Anadolu University, Eskişehir, 32-33.

[7] SAA (2003-2012) General Traffic Statistics of Aircraft, Passenger and Load in Turkey. http://www.dhmi.gov.tr/getBinaryFile.aspx?Type=14\&dosyaID=1049

[8] Ministry of Transport (2007) Hava Trafik Kontrol Hizmetleri Personeli Lisans ve Derecelendirme Yönetmeliği.

[9] Pekmezci, T., Demireli, C. and Batman, G. (2008) İç Müşteri Memnuniyeti: Konya Un Fabrikalarında Bir Uygulama. Dumlupınar Üniversitesi Sosyal Bilimler Dergisi, 
22, 143-156.

[10] ICAO (2001) Annex 11-Air Traffic Services. ICAO Publications, Montreal.

[11] Caruana, A. and Pitt, L. (1997) INTQUAL_An Internal Measure of Service Quality and the Link between Service Quality and Business Performance. European Journal of Marketing, 31, 604-616. https://doi.org/10.1108/03090569710176600

[12] SAA. (2013) AI-ENR. Ankara, 2.1-1.

Submit or recommend next manuscript to SCIRP and we will provide best service for you:

Accepting pre-submission inquiries through Email, Facebook, LinkedIn, Twitter, etc. A wide selection of journals (inclusive of 9 subjects, more than 200 journals)

Providing 24-hour high-quality service

User-friendly online submission system

Fair and swift peer-review system

Efficient typesetting and proofreading procedure

Display of the result of downloads and visits, as well as the number of cited articles Maximum dissemination of your research work

Submit your manuscript at: http://papersubmission.scirp.org/

Or contact tel@scirp.org 